\title{
Genotyping of Hepatitis B Virus by Multiplex PCR in Sistan and Baluchestan Province
}

\author{
Kajal Yoosefi, ${ }^{1}$ Mohsen Taheri, ${ }^{2}$ Soheila Khosravi, ${ }^{3}$ Esmaeel Saneie-Moghadam, ${ }^{3}$ and Amir Hossein \\ Mohagheghi-Fard ${ }^{1, *}$ \\ ${ }^{1}$ Department of Microbiology, Faculty of Medicine, Zahedan University of Medical Sciences, Zahedan, IR Iran \\ ${ }^{2}$ Department of Genetic, Faculty of Medicine, Zahedan University of Medical Sciences, Zahedan, IR Iran \\ ${ }^{3}$ General Physician, Zahedan Blood Transfusion Centre, Zahedan, IR Iran \\ "Corresponding author: Amir Hossein Mohagheghi-Fard, Department of Microbiology, Faculty of Medicine, Zahedan University of Medical Sciences, Zahedan, IR Iran. E-mail: \\ ahmohagh@yahoo.com
}

Received 2015 January 30; Accepted 2015 May 03.

\begin{abstract}
Background: Hepatitis B virus (HBV) has been classified into 8 genotypes (A - H) according to at least $8 \%$ difference in complete nucleotide sequences or more than $4 \%$ in S gene. Different genotypes of HBV have important roles in development of certain disorders as: hepatitis, cirrhosis and hepatocellular carcinoma. Therefore, knowing the distribution of HBV genotypes, have considerable impacts on treatment strategies, vaccination program, diagnosis and prevention.

Objectives: This study aims to determine the prevalence of HBV genotypes in patients infected with the virus in Sistan and Baluchestan province (south-east Iran).

Patients and Methods: In this descriptive study, 163 patients infected with HBV were selected over the first 6 months (beginning from March 2012 onward). All the patients were HBsAg (hepatitis B surface antigen) and HBeAg (extracellular form of HBcAg) positive along with viral load $>10000$ copies/mL. After DNA extraction from the patients' sera, viral genotypes were determined by multiplex polymerase chain reaction (PCR) using special primers for each genotype.

Results: From 163 samples, 154 samples (94.5\%) had D genotype which was dominant genotype; and 9 samples (5.5\%) had mixed genotype of C/D.

Conclusions: This study showed that in Sistan and Baluchestan, like other regions of Iran as well as Mediterranean countries, D genotype is dominant genotype. In additional, C/D mixed genotype is also seen less frequently in this province.
\end{abstract}

Keywords: Genotype, Hepatitis B Virus, Multiplex, Polymerase Chain Reaction

\section{Background}

Hepatitis B is a viral infection and a major cause of viral hepatitis, cirrhosis and hepatocellular carcinoma in different regions of Asia and Africa [1]. According to WHO reports just over 2012 about 2 billion people have been infected with HBV and more than 240 millions suffer from chronic infection whilst, 600,000 pass away from acute and chronic infection per year [2]. HBV is a member of Hepadnaviridae and is classified into 8 genotypes from $\mathrm{A}$ to $\mathrm{H}$ in accordance with at least $8 \%$ difference in complete nucleotide sequences or more than $4 \%$ in $S$ gene $[3,4]$. Though, some researchers have categorized HBV into 10 genotypes (A to J) [5-8]. As in case of genotypes A to F considerable data is available concerning their geographic distribution, differential sequences and frequency of strain spread [9] in contrast to genotype G which, in spite of efforts by Kato et al. yet no significant information is presented regarding its epidemiology and incidence. So far, only one case of genotype $G$ has been documented from
France, Germany and USA $[10,11]$.

Furthermore, few isolates of genotypes $\mathrm{H}$ and $\mathrm{F}$ are related and show similar geographic distribution [9]. Although, all genotypes of HBV induce infection in liver but demonstrate different clinical features and potency [12-14]. Patients infected by genotype $\mathrm{C}$ or $\mathrm{D}$ indicated more mutations in promoter region of nucleus and in comparison with $A$ and $B$ genotypes show less effective response to interferon therapy hence, spread of infection toward cirrhosis and hepatocellular carcinoma is accelerated [15].

In Sunbul et al. study in Turkey, genotype D was detected in $88.7 \%$ patients [16]. As Iran is located in Mediterranean region, it is assumed that genotype $\mathrm{D}$ is dominant [17]. Eftekhari et al. have reported genotype D the only existing genotype in Iran and other genotypes have not been described however, their study was just restricted to Tehran and Fars provinces and which is not extendible to other parts of the country [18]. 


\section{Objectives}

Different genotypes of HBV have different clinical manifestations hence; the objective of this study was to determine HBV genotype in infected individuals in Sistan and Baluchestan (south-east Iran) province.

\section{Patients and Methods}

In this descriptive-analytical study, we chose all patients who were referred to hepatitis clinic in Zahedan blood transfusion centre from March to August 2012 once their written consents were taken. The inclusive criteria for sera samples were: positive HBeAg as well as positive HBsAg, the latter was proved by ELISA kit (Siemens from Germany) and viral load of more than 10,000 copies $/ \mathrm{mL}$. The number of samples selected was 163 and since transmission of HBV in this province is mainly congenital and presence of one genotype in a family is shared with other members therefore, from each family only one member was included in our investigation. In case any sample was HBsAg positive but at the same time anti-HDV, anti-HCV and anti-HIV were also positive, was excluded from our study. Moreover, if any sample had viral load less than 10,000 copies/mL as well as HBeAg negative was expelled too. The selected sera were then incubated at $-43^{\circ} \mathrm{C}$ followed by DNA isolation by a specific kit manufactured by Roche (Germany), the extracted DNAs were stored at $-22^{\circ} \mathrm{C}$ for further assays.

The purified DNAs were then subjected to multiplex PCR in addition to exact primers of different genotypes of HBV with specified sequences, as described formerly [9]. All PCR cocktails had final volume of $20 \mu \mathrm{L}$ after utilization of Master Mix (of Genet Bio company) consisting Taq DNA polymerase 1 unit/10 $\mu \mathrm{L}$, primers $4 \mathrm{mM}$, KCL $80 \mathrm{mM}$, Tris-HCL $20 \mathrm{mM}, \mathrm{MgCl}$, enzyme stabilizer, sediment, loading dye, $\mathrm{pH}=9,0.5 \mathrm{mM}$ of each as well as dATP (Deoxycytidine triphosphate), dCTP (Deoxycytidine triphosphate), dGTP (Deoxycytidine triphosphate), dTTP (Deoxycytidine triphosphate). Moreover, to Master Mix 1.2 $\mu \mathrm{L}$ of extracted DNA plus $0.5 \mu \mathrm{L}$ of primers (six pairs) were added and through addition of distilled water the final volume was equal to $20 \mu \mathrm{L}$.

PCR programming was based on protocol introduced by Kirschberg et al. [9] with some modification as following. The cycling conditions were: an initial predenaturation at $95^{\circ} \mathrm{C}$ for 15 minutes, subsequently denaturation $94^{\circ} \mathrm{C}$ for 1 minute, annealing at $60^{\circ} \mathrm{C}$ for 1 minutes, an extension at $72^{\circ} \mathrm{C}$ for 1 minute for 40 cycles besides a final extension at $72^{\circ} \mathrm{C}$ for 10 minutes (Table 1 ). Once, PCR cycles were completed the product was subjected onto electrophoresis on $2.5 \%$ agarose gel. The gel was then stained by ethid- ium bromide and the results adjacent to DNA ladder (50 bp) were looked into under UV light. However, primer sequences and sizes of each PCR product corresponding to different genotypes are represented in Table 1.

\subsection{Statistical Analysis}

All statistical analyses were performed using SPSS-15 software, genotypes frequencies were completed by means of cross-tab and $\chi^{2}$ analysis. P value $<0.05$ is considered as level of significance.

\section{Results}

In this study 163 samples, from individuals infected by HBV, were collected including 117 (71.8\%) males and 46 (28.2\%) females. The average age of victims was $35 \pm 13$ years, all sera were HBsAg and $\mathrm{HBeAg}$ positive and $\mathrm{HBcAg}$ negative. Modes of transmission were congenital $56.4 \%$ as well as others including: through homodialysis, continuous dental services, tattooing in addition to suspected intercourse all together comprised about $43.6 \%$.

All sera samples contained HBV DNA which were extracted by above mentioned protocol and were then subjected onto multiplex PCR. Findings were evident for genotype D in 154 specimens (94.5\%) and 9 (5.5\%) had mixture of C/D genotype (Figure 1).

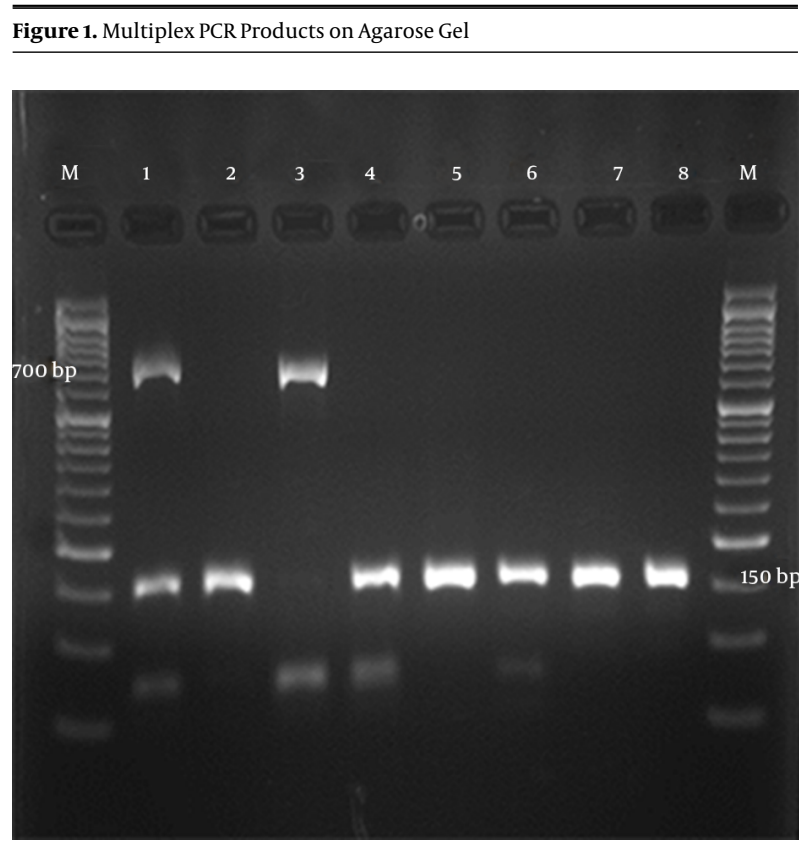

Lane 1 shows mixture of genotype $C / D$, lane 2 and 3 indicate positive control for genotype D and C respectively; lanes 4, 5, 6, 7 and 8 collectively specify genotype D. 
Table 1. Primer Sequences and Sizes of the Products

\begin{tabular}{|c|c|c|}
\hline Genotype and Primers & \multirow{2}{*}{ Sequence } & \multirow{2}{*}{$\frac{\text { Size of Amplification, bp }}{370}$} \\
\hline A & & \\
\hline Sens (nt 2331- 2360) & 5-CGGAAACTACTGTTGTTAGACGACGGGAC-3 & \\
\hline Anti-sens (nt 2701- 2665) & 5-AATTCCTTTGTCTAAGGGCAAATATTTAGTGTGGG-3 & \\
\hline B & & 190 \\
\hline Sens (nt 1470 - 1491) & 5-CCGCTTGGGGCTCTACCGCCCG-3 & \\
\hline Anti-sens (nt 1660 - 1633) & 5-CTCTTATGCAAGACCTTGGGCAGGTTCC-3 & \\
\hline C & & 701 \\
\hline Sens (nt 2706 - 2741) & 5-CCTGAACATGCAGTTAATCATTACTTCAAAACTAGG-3 & \\
\hline Anti-sens (nt 192 - 165) & 5-AGCAGGGGTCCTAGGAATCCTGATGTTG-3 & \\
\hline D & & 147 \\
\hline Sens (nt 2843-2870) & 5-ACAGCATGGGGCAGAATCTTTCCACCAG-3 & \\
\hline Anti-sens (nt 2990 - 2966) & 5-CCTACCTTGTTGGCGTCTGGCCAGG-3 & \\
\hline $\mathbf{E}$ & & 787 \\
\hline Sens (nt 2093 - 2122) & 5-CTAATGACTCTAGCTACCTGGGTGGGTGTA-3 & \\
\hline Anti-sens (nt 2880 - 2853) & 5-CCATTCGAGAGGGACCGTCCAAGAAAGC-3 & \\
\hline $\mathbf{F}$ & & 481 \\
\hline Sens (nt 2843 - 2871) & 5-ACAGCATGGGAGCACCTCTCTCAACGACA-3 & \\
\hline Anti-sens (nt 109-83) & 5-AGAGGCAATAGTCGGAGCAGGGTTCTG-3 & \\
\hline
\end{tabular}

\section{Discussion}

In this study, similar to the other researches carried out in different parts of Iran and Middle East, genotype D was predominant. According to the data published roughly $1 \%$ $3 \%$ of Iranian population are assumed to be carriers of HBV but with various frequencies in different provinces for instance; in Fars province this figure is $1.7 \%$ while for Sistan and Baluchestan is more than 5\% [19]. Eight genotypes of $\mathrm{HBV}(\mathrm{A}-\mathrm{H})$ are differentiated according to at least $8 \%$ difference in complete nucleotide sequences or more than $4 \%$ in S gene [20]. Genotypes of HBV do not indicate any particular geographic distribution. The latter pattern has shifted greatly specially in countries where more immigration takes place and it is anticipated that with escalation of immigration worldwide the former geographic distribution may seem more fluctuating. Hence, there are possibilities of recombination between genotypes e.g. A with D or A with C or B with C and so on. Although, there are certain structural and clinical differences between genotypes but recombination with other strains would create more variations and definite evidences support the concluding theory. Nevertheless in most of the studies, in spite of geographical pattern of genotypes distribution, regretfully only genotypes A with D and B with C have been compared and therefore, there is no clear consensus regarding virulence of different genotypes. Ideally, we need a prospective study in which neonates who have congenital infections with various genotype of A, B, C, D, E, F and G be taken under scrutiny up to youth in order to answer questions on differences between genotypes after chronic infection of HBV [21].

In regions where $\mathrm{HBV}$ is endemic, infection with more than one genotype frequently ends up to recombinant strain and possibility of co-infection or super-infection with other genotypes in a particular host. Furthermore, mixture of different genotypes in patients suffering from chronic hepatitis $\mathrm{B}(\mathrm{CHB})$, in comparison with those who are infected with a single genotype, is related to higher viral load and acceleration of HBV replication in vitro. In a study by Cao in China, the prevalence of genotype mixture in HBsAg carriers who were asymptomatic, hepatocellular carcinoma (HCC) sufferers and CHB victims was reported as: $5.4 \%, 10.6 \%$ and $13.7 \%$ respectively. Genotype mixture (mostly B and C) in comparison with C alone is correlated with more viral load and a more severe disease [5]. In addition according to above report co-infection and superinfection with various genotypes has poorer prognosis of HBV. In another study by Fang et al., a mixture of genotypes C/D in China has been documented [22]. Similarly, Noorali 
et al. in addition to genotype $\mathrm{D}$ which is predominant in Pakistan, have described co-infection of genotypes $\mathrm{B} / \mathrm{D}$ as well as C/D [23].

As far as Iran is concerned, information on HBV genotype is limited nonetheless, Mohammadnejad et al. in eastern Azerbaijan [24], Moradi et al. in Golestan province [25], Eftekhari et al. in southern provinces [18], Sharifi et al. in Kerman, Esfahan and Yazd [26] as well as Dokanehiifard and Bidmeshkipour in Kermanshah province [27] have unambiguously announced genotype $\mathrm{D}$ as prevailing one. As discrepancy of genotypes in a certain country is foreseeable, so HBV genotyping sounds necessary in different regions.

As a matter of fact, at beginning classification of HBV was based on complete nucleotide sequencing of genome but later on the former gradually changed to sequencing of single genes or parts of them in order to facilitate the comparison between different strains. In search for alternate techniques in lieu of sequencing led to trial of Restriction Fragment Length Polymorphism (RFLP) for PCR products of HBV. Therefore, $S$ gene or combination of both pre $S$ and $S$ genes are employed for genotyping. In a study by Mizokami et al. who compared complete genome by RFLP analysis with that of $S$ gene, concluded the latter alone is sufficient for differentiation between all six genotypes i.e. A - F [28]. Another procedure used for genotyping was analysis of PCR products i.e. hybridization after PCR or so called line probe assay. Naito et al. explicated genotyping via PCR by means of specific primers [29]. Similarly, Usuda et al. through utilization of genotypes dissimilarity in pre S2 gene, applied monoclonal antibodies against specific epitopes and for discrimination between genotypes A to $\mathrm{F}$ they used ELISA [30]. In another investigation, Alavian et al. extracted genotype D from 109 patients by another protocol known as: INN-LiPA hybridation [19]. However, Mohammadnejad et al., in eastern Azerbaijan for HBV genotyping put into practice sequencing followed by analysis of products [24]. In contrast to former techniques, Dokanehiifard and Bidmeshkipour in Kermanshah employed RFLP for genotyping [27] whereas, Moradi et al. by utilization of specific commencers of A-F genotypes could differentiate between strains in samples obtained in Golestan province [25].

As far as multiplex PCR is concerned, it is useful for rapid diagnosis plus deletion of repeating gene in a long chain, so in this procedure couple of primers is added to a PCR cocktail aiming in finding of different genes that leads to PCR products with various sizes. Multiplex PCR is advantageous in terms of saving time and reagents as well. In present study we employed multiplex PCR due to its sensitivity, specificity and cost effectiveness besides this protocol was approved by Kirschberg et al. in their study
[9]. Therefore, we extracted DNA from sera of HBV infected individuals and then through PCR, differentiation of A-F genotypes by a single reaction was obtainable.

Furthermore, this technique is quite appropriate for epidemiologic as well as diagnostic purposes in areas like Iran with relatively high frequency of HBV. Multiplex PCR is suitable for diagnoses of co-infections with various genotypes as well. The current study can also lead to find new ways for remedy of HBV victims and further investigations would aid in identification of various sera and subtypes of the virus in question. Moreover, such investigation on HBV serotyping would assist in reconstruction of history of evolution of certain strains and of course would complement our knowledge about genetic information of HBV.

\section{Acknowledgments}

This study was financially supported by the deputy of research centre at the Zahedan University of Medical Sciences (project No. 91-2497). Moreover, the authors would like to express their gratitude to all patients who helped in collection of samples and of course staff of Zahedan blood transfusion centre for their kind and generous cooperation.

\section{Footnotes}

Authors' Contribution: All authors had equal role in design, work, statistical analysis and manuscript writing.

Funding/Support: Zahedan University of Medical Sciences.

\section{References}

1. Wang S, Huang D, Sun S, Ma W, Zhen Q. Interleukin-10 promoter polymorphism predicts initial response of chronic hepatitis B to interferon alfa. Virol J. 2011;8:28. doi: 10.1186/1743-422X-8-28. [PubMed: 21251301].

2. World Health Organization . Hepatitis B WHO; [updated July 2015] Available from: http://www.who.int/mediacentre/factsheets/fs204/ en/.

3. Knipe DM, Howley P. Fields virology. 6 ed. Washington D.C: LWW Press; 2001. pp. 2971-3036.

4. Fung SK, Lok AS. Hepatitis B virus genotypes: do they play a role in the outcome of HBV infection?. Hepatology. 2004;40(4):790-2. doi: 10.1002/hep.1840400407. [PubMed: 15382157].

5. Cao GW. Clinical relevance and public health significance of hepatitis B virus genomic variations. World J Gastroenterol. 2009;15(46):5761-9. [PubMed: 19998495]

6. Tran TT, Trinh TN, Abe K. New complex recombinant genotype of hepatitis B virus identified in Vietnam. J Virol. 2008;82(11):5657-63. doi: 10.1128/JVI.02556-07. [PubMed: 18353958].

7. Olinger CM, Jutavijittum P, Hubschen JM, Yousukh A, Samountry $\mathrm{B}$, Thammavong $\mathrm{T}$, et al. Possible new hepatitis $\mathrm{B}$ virus genotype, southeast Asia. Emerg Infect Dis. 2008;14(11):1777-80. doi: 10.3201/eid1411.080437. [PubMed: 18976569]. 
8. Tatematsu K, Tanaka Y, Kurbanov F, Sugauchi F, Mano S, Maeshiro T, et al. A genetic variant of hepatitis B virus divergent from known human and ape genotypes isolated from a Japanese patient and provisionally assigned to new genotype J.JVirol. 2009;83(20):10538-47. doi: 10.1128/JVI.00462-09. [PubMed: 19640977].

9. Kirschberg O, Schuttler C, Repp R, Schaefer S. A multiplex-PCR to identify hepatitis B virus-enotypes A-F. J Clin Virol. 2004;29(1):39-43. [PubMed: 14675868].

10. Kato H, Orito E, Gish RG, Bzowej N, Newsom M, Sugauchi F, et al. Hepatitis B e antigen in sera from individuals infected with hepatitis B virus of genotype G. Hepatology. 2002;35(4):922-9. doi: 10.1053/jhep.2002.32096. [PubMed: 11915040].

11. Kato H, Orito E, Gish RG, Sugauchi F, Suzuki S, Ueda R, et al. Characteristics of hepatitis $B$ virus isolates of genotype $G$ and their phylogenetic differences from the other six genotypes (A through F). J Virol. 2002;76(12):6131-7. [PubMed: 12021346].

12. Aghakhani A, Hamkar R, Zamani N, Eslamifar A, Banifazl M, Saadat A, et al. Hepatitis B virus genotype in Iranian patients with hepatocellular carcinoma. Int J Infect Dis. 2009;13(6):685-9. doi: 10.1016/j.ijid.2008.10.009. [PubMed:19138545].

13. Chandra PK, Biswas A, Datta S, Banerjee A, Panigrahi R, Chakrabarti $S$, et al. Subgenotypes of hepatitis B virus genotype D (D1, D2, D3 and D5) in India: differential pattern of mutations, liver injury and oc cult HBV infection.J Viral Hepat. 2009;16(10):749-56. doi: 10.1111/j.13652893.2009.01129.x. [PubMed: 19457142].

14. Baig S, Siddiqui A, Chakravarty R, Moatter T. Hepatitis B virus subgenotypes D1 and D3 are prevalent in Pakistan. BMC Res Notes. 2009;2:1. doi: 10.1186/1756-0500-2-1. [PubMed: 19121226].

15. Salem F, Aghasadeghi MR, Javadi F, Roohvand F, Joolaee M, Bahramali G. Using RFLP-PCR and direct sequencing to determine HBV genotypes in intravenous drug user patients in Tehran province [in Persian]. J Iran Med Univ. 2010;17(71):56-64.

16. Sunbul M, Leblebicioglu H. Distribution of hepatitis B virus genotypes in patients with chronic hepatitis B in Turkey. World J Gastroenterol. 2005;11(13):1976-80. [PubMed:15800989].

17. Poustchi H, Mohamadnejad M, Malekzadeh R. Hepatitis B virus infection in Iran. Iran J Clin Infect Dis. 2007;2(1):37-51.

18. Eftekhari Y, Kazemi Arababadi M, Hakimi H, Rezazadeh Zarandi E. Common HBV genotype in southeastern Iranian patients. Arch Iran Med. 2010;13(2):147-9. [PubMed: 20187670].

19. Alavian SM, Fallahian F, Lankarani KB. The changing epidemiology of viral hepatitis B in Iran. J Gastrointestin Liver Dis. 2007;16(4):403-6.
[PubMed: 18193122].

20. Chen J, Yin J, Tan X, Zhang $H$, Zhang $H$, Chen B, et al. Improved multiplex-PCR to identify hepatitis B virus genotypes A-F and subgenotypes B1, B2, C1 and C2. J Clin Virol. 2007;38(3):238-43. doi: 10.1016/j.jcv.2006.12.007. [PubMed: 17224304].

21. Kidd-Ljunggren K, Miyakawa Y, Kidd AH. Genetic variability in hepatitis B viruses. J Gen Virol. 2002;83(Pt 6):1267-80. doi: 10.1099/0022-131783-6-1267. [PubMed: 12029141].

22. Fang ZL, Zhuang H, Wang XY, Ge XM, Harrison TJ. Hepatitis B virus genotypes, phylogeny and occult infection in a region with a high incidence of hepatocellular carcinoma in China. World J Gastroenterol. 2004;10(22):3264-8. [PubMed: 15484297].

23. Noorali S, Hakim ST, McLean D, Kazmi SU, Bagasra O. Prevalence of Hepatitis B virus genotype D in females in Karachi, Pakistan. J Infect Dev Ctries. 2008;2(5):373-8. [PubMed:19745506].

24. Mohammadnejad L, Farajnia S, Parivar K, Naghili B, Yousefzadeh Kheirnagsh R. Hepatitis B virus genotypes in eastern Azerbaijan, Northwest Iran. Arch Iran Med. 2012;15(7):446-8. [PubMed: 22724883].

25. Moradi A, Kazeminejad V, Molana AA, Bazoori M. HBV genotypes in Golestan province of Iran [in Persian]. Sci J Iran Blood Transfus Org. 2010;7(1):27-33.

26. Sharifi Z, Gharebaghian A, Noroozi M. Prevalence of hepatitis B virus genotypes to be determined by sequencing in blood donors in Kerman, Esfahan and Yazd [in Persian]. Sci J Iran Blood Transfus Organ. 2010;6(4):248-56.

27. Dokanehiifard S, Bidmeshkipour A. Study of hepatitis B virus (HBV) genotypes in Kermanshah province, West of Iran. J Biol Sci. 2009;1(1):113-20.

28. Mizokami M, Nakano T, Orito E, Tanaka Y, Sakugawa H, Mukaide M, et al. Hepatitis $B$ virus genotype assignment using restriction fragment length polymorphism patterns. FEBS Lett. 1999;450(1-2):66-71. [PubMed: 10350059].

29. Naito H, Hayashi S, Abe K. Rapid and specific genotyping system for hepatitis B virus corresponding to six major genotypes by PCR using type-specific primers. J Clin Microbiol. 2001;39(1):362-4. doi: 10.1128/JCM.39.1.362-364.2001. [PubMed: 11136801].

30. Usuda S, Okamoto H, Tanaka T, Kidd-Ljunggren K, Holland PV, Miyakawa Y, et al. Differentiation of hepatitis B virus genotypes D and $\mathrm{E}$ by ELISA using monoclonal antibodies to epitopes on the preS2-region product. J Virol Methods. 2000;87(1-2):81-9. [PubMed: 10856755]. 